Pamiętnik Literacki 2021, 2, s. 225-234

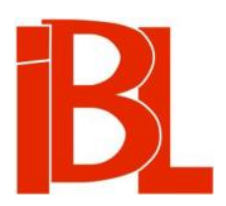

\title{
O pierwszych przekładach Konstytucji 3 Maja
}

Anna Grześkowiak-Krwawicz 
Pamiętnik Literacki CXII, 2021, z. 2, PL ISSN 0031-0514

DOI: $10.18318 / \mathrm{pl} .2021 .2 .16$

ANNA GRZEŚKOWIAK-KRWAWICZ Instytut Badań Literackich PAN, Warszawa

\section{O PIERWSZYCH PRZEKŁADACH KONSTYTUCJI 3 MAJA}

Sensacja, jaką wzbudziła w Europie przyjęta 3 maja 1791 Ustawa rzadowa, jest rzeczą znana, podobnie jak propaganda nowej Konstytucji przez jej twórców, a przede wszystkim przez Stanisława Augusta ${ }^{1}$. Jednak choć od dawna wiadomo, iż szybko pojawiły się edycje nowego prawa w językach obcych ${ }^{2}$, nikt nie poświęcił owym przekładom większej uwagi. Przedmiotem tego artykułu jest właśnie próba przyjrzenia się i porównania trzech najwcześniejszych (jak się wydaje) tłumaczeń Konstytucji - na języki francuski, angielski i niemiecki. Każde z nich powstało $\mathrm{w}$ innych okolicznościach, odmienna była historia ich funkcjonowania i zasięgu, po trosze różny zresztą był także cel ich autorów. Różnice można zaobserwować również w, by tak rzec, postawach translatorskich - stosunku do oryginału, ale też i w jakości przekładu. Choć ważnym przedmiotem badań są tu teksty, niektóre użyte w nich sformułowania, a nawet konkretne słowa, nie jest to analiza językoznawcza. Raczej będą to rozważania z pogranicza dziejów propagandy, historii idei, historii języka politycznego i, w pewnym sensie, historii literatury - wszak Konstytucja 3 Maja, choć nikt tego nie dostrzegł, to jedno $z$ bardziej udanych dzieł literackich polskiego oświecenia.

Nie tylko przekłady różnią się między sobą, odmienna jest także nasza wiedza o nich. Najdokładniej znamy historię tłumaczenia angielskiego, którego na życzenie króla podjął się polski przedstawiciel dyplomatyczny w Londynie Franciszek Bukaty, otrzymawszy wysłany 7 maja tekst Ustawy ${ }^{3}$. Praca, w której Bukatemu pomagał zapewne ktoś $\mathrm{z}$ jego angielskich przyjaciól, trwała krótko. Jak donosiło ogłoszenie jej wydawcy, Johna Debretta ${ }^{4}$, edycja angielska ukazała się drukiem 31 maja $^{5}$. Autora znamy także w przypadku tłumaczenia niemieckiego. Był nim

1 Zob. P. U g n i e w s ki, Między absolutyzmem a jakobinizmem. „Gazeta Lejdejska” o Francji i Polsce 1788-1794. Warszawa 1998, s. 81-89.

$2 \quad$ Notowała je już Bibliografia polska K. Estreichera.

3 Stanisław August, list do F. Bukatego, 7 V 1791 (Warszawa). Cyt. za: W. Kalin ka, Ostatnie lata panowania Stanisława Augusta. Dokumenta do historii drugiego i trzeciego podziału. Cz. 2. Poznań 1868, s. 187.

4 Zob. anons z „The Morning Chronicle” (1791, nr z 30 V): „Tomorrow will be published an authentic copy of the new constitution of Poland, established by the Revolution May 3, 1791, translated from the Polish".

5 New Constitution of the Government of Poland, established by the Revolution, the Third of May, 1791. London 1791. Na stronie: https://books.google.pl/books?id=SdZhAAAAcAAJ\&printsec=frontcove r\&hl=pl\&source=gbs_ge_summary_r\&cad=0\#v=onepage\&q\&f=false (data dostępu: 5 I 2021). Eg- 
Karol Glave Kobielski, który, co prawda, podpisał się pod swoim dziełkiem tylko inicjałami „K. G.”, ale ofiarowując egzemplarz Stanisławowi Potockiemu, dedykację opatrzył już nazwiskiem ${ }^{6}$. Tłumaczenie to do tej pory umykało bibliografom, nie stanowi bowiem wydania samoistnego, lecz znajduje się w drukowanym przez Michała Grölla niemieckojęzycznym opisie wydarzeń 3 maja 1791. Przykładem jest tu Karol Estreicher, który wymienił w swojej bibliografii książeczkę Glavego ${ }^{7}$, ale nie zorientował się, że przekład Konstytucji z 1792 roku $^{8}$ odnotowany przez niego $\mathrm{w}$ innym miejscu jako anonimowy, $\mathrm{w}$ istocie był przedrukiem tłumaczenia jej fragmentu ${ }^{9}$. Data pierwszego wydania jest trudna do ustalenia, prawdopodobnie ukazało się ono stosunkowo szybko, bo opisy „rewolucji” polskiej budziły największe zainteresowanie bezpośrednio po jej przeprowadzeniu, ale konkretnego potwierdzenia tej hipotezy nie ma ${ }^{10}$. Jeszcze mniej wiemy o najbardziej znanym, wydanym u Piotra Dufoura przekładzie francuskim ${ }^{11}$. Przede wszystkim nie znamy jego autora, natomiast datę druku można ustalić dość dokładnie. W „Journal hebdomadaire de la Diète" ukazywał się ten przekład w odcinkach dopiero od początku lipca ${ }^{12}$, ale już wcześniej, bo od 21 czerwca, drukowała go Gazeta Lejdejska ${ }^{13}$. Ponieważ jest wysoce prawdopodobne, iż jej wydawca oparł się nie na edycji warszawskiej, ale na przedruku paryskim, który w tej sytuacji nie ukazał się zapewne przed 15 czerwca $^{14}$; biorąc pod uwagę szybkość poczty, druku itd., wolno sądzić,

zemplarze edycji pierwszej należą do rzadkości, znacznie częściej spotykane jest wydanie drugie. Zob. też Constitution. Hasło w: Estr. XV-XVIII, t. 14, s. 376.

6 Die Regierungs-Ordnung. W: Geschichte der Pohlnischens Staats-Veranderung vom 3 May 1791. Nach dem Pohlnischen Berichte der Warschauer National-Zeitung. Von K. G [lave]. Warschau [1791?], s. 65-103. Na stronie: https://polona.pl/item/geschichte-der-pohlnischen-staats-veranderung-vom-3-may-1791-nach-dem-pohlnischen,MTE5Njc2OA/109/\#info:metadata (data dostępu: 5 I 2021). Egzemplarz znajduje się w Bibliotece Wilanowskiej.

7 Glave Kobielski Karol Fryderyk. Hasło w: Estr. XV-XVIII, t. 17, s. 162.

8 Neue Konstitution von Pohlen, vom 3. May 1791. [Warschau?] 1792. https://polona.pl/item/neuekonstitution-von-pohlen-vom-3-may-1791,MzAwNjM2NA/4/\#info:metadata (data dostępu: 5 I 2021). Zob. też Konstitution (Neue). Hasło w: Estr. XV-XVIII, t. 20, s. 35.

9 Glavego jako tłumacza Konstytucji wymienił za XVIII-wiecznymi czasopismami niemieckimi H. W a hle (Die polnische Verfassung vom 3. Mai 1791 im zeitgenössischen deutschen Urteil. „Jahrbücher für Geschichte Osteuropas" $1971\langle$ t. 19〉, z. 3 〈September〉, s. 365).

10 Przedruk ukazał się latem w „Staatsanzeigen” (1791〈t. 16〉, z. 63. Na stronie: http://ds.ub.uni-bielefeld.de/viewer/image/1944381_016 (data dostępu: 5 I 2021).

11 Forme constitutionelle décrétée par acclamation dans la séance du 3. Mai, et sanctionnée à l'unanimité, dans la séance suivante du 5. Mai 1791. Varsovie 1791. Na stronie: https://polona.pl/item/ forme-constitutionelle-decretee-par-acclamation-dans-la-seance-du-3-mai-et-sanctionnee-a,NDE4 Njk3Nw/4/\#info:metadata (data dostępu: 15 I 2021).

12 Chodzi o numery 26-30 (Juillet-Août) z 1791 roku (na stronie: https://gallica.bnf.fr/ark:/12148/ cb32801406f/date1791.liste (data dostępu: 5 I 2021)). Zob. też J. Kowe cki, wstęp w: Konstytucja 3 Maja 1791. Oprac. J. Kow e cki. Przedm. B. Le śn od or s ki. Warszawa 1981, s. 57.

13 „Nouvelles extraordinaires de divers endroits” [Gazeta Lejdejska] 1791, nr 49, 21 VI. Na stronie: https://babel.hathitrust.org/cgi/pt?id=njp.32101076535705\&view=1up\&seq (data dostępu: 15 I 2021 ).

14 Forme constitutionelle décrétée par acclamation dans la séance du 3. Mai, et sanctionnée à l'unanimité, dans la séance suivante du 5. Mai 1791. D’après l'original imprimée à Varsovie. Paris 1791. Na stronie:https://polona.pl/item/forme-constitutionelle-de-la-pologne-decretee-par-acclamationdans-la-seance-du-3-mai-et,OTAxOTY1OA/0/\#info:metadata (data dostępu: 15 I 2021). Ówczesna 
że wersja Dufourowska wyszła nie później niż w połowie maja. Zdaje się to potwierdzać informacja w liście króla do Filippa Mazzeiego z 25 maja, iż do listu dołącza „un exemplaire pour vous de la traduction de notre forme constitutionelle"15. Choć nie napisano tam wprost, o jakie tłumaczenie chodzi, można odnieść wrażenie, że był to właśnie druczek Dufoura.

Wspomniane wyżej przedruki pokazują, iż wszystkie trzy przekłady miały „dalsze życie”, a zatem spełniły swój podstawowy cel, jakim była propaganda Konstytucji i zarazem były odpowiedzią na zapotrzebowanie publiczności europejskiej na dokładną informację o niej. $Z$ tym że trzeba pamiętać, iż żaden $z$ nich nie był dla tej publiczności pierwotnym źródłem wiedzy o treści dokumentu. Wydarzenia w Polsce, podobnie jak tekst nowego prawa, wywołały ogromne zainteresowanie już od chwili, kiedy pierwsze wiadomości o nich dotarły za granicę ${ }^{16}$. Dość dokładne ekscerpty z Ustawy rzadowej, zapewne czerpane od polskich przedstawicieli dyplomatycznych, publikowały już w maju gazety międzynarodowe, prasa francuska (około 25-30 maja) ${ }^{17}$ i angielska (między $23-30$ maja) ${ }^{18}$. W to zainteresowanie wpisały się także pełne tłumaczenia Konstytucji, acz w różnym stopniu. Największy sukces odniósł chyba Bukaty. Co prawda, jego przekład był adresowany wyłącznie do odbiorcy anglojęzycznego, a więc publiczność była dość ograniczona, za to reakcja bardzo żywa - świadczy o tym nie tylko drugie wydanie tłumaczenia ${ }^{19}$, ale też fakt, że przekład został przedrukowany w wersji pełnej w trzech gazetach londyńskich, obszernie zaś streszczony jeszcze w dwóch ${ }^{20}$. Zważywszy, iż prasa londyńska była źródłem informacji o sprawach zagranicznych dla całej Anglii, miał szansę dotrzeć do bardzo szerokiej publiczności. Dzieje tłumaczenia Glavego nie są tak

seria bibliograficzna Feuille de correspondance de librairie (T. 1. Paris 1791, s. 76, poz. 483) odnotowała ukazanie się przedruku pod datą 26 VI 1791 (na stronie: https://babel.hathitrust.org/cgi/ pt?id=nyp.33433069133639\&view=lup\&seq=86 〈data dostępu: 15 I 2021〉).

Stanisław August, list do F. Mazzeiego, z 25 V 1791. Odpis W. Łukas zewicz. Bibl. Narodowa w Warszawie, BN akc. 11/356, s. 521 (na stronie: https://polona.pl/item/listy-do-filippomazei-ego-z-lat-1788-1791,MTY3NzQ5NzU/1/\#info:metadata (data dostępu: 24 II 2021)).

O reakcjach na Konstytucje 3 Maja zob. M. H a n d els m a n, Konstytucja 3 maja r. 1791, a spótczesna opinia publiczna we Francji. „Przegląd Historyczny” 1909 (t. 9). - A. Za h o r s ki, Moniteur lat 1789-1795 o sprawach polskich. Jw., 1966 (t. 57). - Wa hle, op. cit., - A. Grześ k owiak - Krw a wi c z, Sensacja - informacja - komentarz. Londyńska prasa informacyjna o polskich „rewolucjach” 1791 roku. „Kwartalnik Historyczny” 2009, nr 3. - A. V u ill e z, La Perception française des affaires de Pologne (1791-1795). Praca magisterska napisana pod kier. E. D zi e m b o w s ki ego na Université de Franche-Comté. Besançon 2015 (uprzejmie dziękuję za użyczenie mi jej przez autora).

17 Zob. Handelsman, op. cit., s. 85 n. - Vuillez, op. cit., s. 108 n.

18 Zob. Grześkowiak-Krwawicz, op. cit., s. 103.

19 Miało ono taki sam tytuł, jak pierwsze, $z$ tym że $z$ adnotacją „The second edition” (na stronie: https:// polona.pl/item/new-constitution-of-the-government-of-poland-established-by-the-revolution-thethird-of,MTEwOTI2Mw/7 /\#info:metadata (data dostępu: 15 I 2021)). Ta właśnie edycja będzie tu cytowana. Zachowano oryginalną pisownię XVIII-wieczną we wszystkich cytatach z obcojęzycznych przekładów Konstytucji. W artykule przywołuje się następujące jej wydanie w języku polskim: Konstytucja 3 Maja 1791. Na podstawie tekstu Ustawy rzadowej z Archiwum Sejmu Czteroletniego przechowywanego $w$ Archiwum Głównym Akt Dawnych $w$ Warszawie. Oprac., wstęp A. G r z e śkowiak-Krwawicz. Warszawa 2018. Na stronie: http://agad.gov.pl/wp-content/uploads/2018/12/Konstytucja-3-maja_PL-v5.pdf (data dostępu: 15 I 2021). 
dobrze zbadane. Wiemy jednak, że nie tylko wyszło drugie, osobne wydanie, choć nie wiemy, gdzie się ukazało ${ }^{21}$, lecz także, iż pełna wersja książki Glavego, zawierająca zarówno Konstytucję, jak opis wydarzeń 3 maja, była dostępna dla czytelników niemieckich. Książkę sprzedawano i w Warszawie, i w Lipsku ${ }^{22}$. Że wzbudziła zainteresowanie, potwierdza fakt, iż powoływano się na nią w prasie ${ }^{23}$, a także iż z książki tej właśnie treść Konstytucji została in extenso przedrukowana w Schlözerowskim „Staatsanzeigen”, z obszernym komentarzem wydawcy ${ }^{24}$.

Paradoksalnie, nie do końca sukcesem propagandowym była edycja francuska, z racji języka potencjalnie adresowana do najszerszej publiczności. Co prawda, jej tekst był drukowany w międzynarodowej Gazecie Lejdejskiej, a paryski przedruk ukazał się stosunkowo szybko, być może $z$ inicjatywy Mazzeiego, jednak w pewnym sensie było to już za późno. Ogromne zainteresowanie wypadkami w Polsce, przynajmniej we Francji, osłabło, szczególnie po 20 czerwca, czyli po ucieczce Ludwika XVI do Varennes. Nie widać, by prasa francuska opublikowała tekst Konstytucji. Wymowne jest, że nawet skądinąd bardzo Polsce życzliwy Jean Luzac drukował Ustawe aż trzy tygodnie (od 21 czerwca do 15 lipca), niejako spychając ją na margines, wobec natłoku informacji z Francji, wyraźnie uwzględniając większe zainteresowanie czytelników sytuacja w tej ostatniej ${ }^{25}$. Choć więc zasięg przekładu francuskiego był niemały, jednak można odnieść wrażenie, że nie do końca spełnił nadzieje wydawców. Nie wiemy, co prawda, kto konkretnie dokonał przekładu, ale jego bardzo staranna forma, oddająca wszelkie niuanse Konstytucji, zdaje się sugerować, jeśli nie udział w tym przedsięwzięciu twórców Ustawy, to konsultacje z nimi, a zarazem spora wagę przywiązywaną do tego przekładu i zapewne także do jego wpływu na opinię międzynarodową.

Prowadzi to do kolejnej kwestii, bardziej szczegółowych celów, jakie chcieli osiaggnąc wydawcy przekładów Konstytucji. Wspólne było niewątpliwie pragnienie zaprezentowania nowego prawa opinii międzynarodowej, ale każda $z$ edycji pokazywała je trochę inaczej. Najbardziej ascetyczną formą odznaczała się edycja francuska, ograniczająca się do samego tekstu Ustawy nawet bez kończącej ją Deklaracji Stanów Zgromadzonych ${ }^{26}$. Można odnieść wrażenie, iż wydawca uznał decyzje

21 Domniemanie K. Estreich era (Estr. XV-XVIII, t. 20, s. 35), iż był to druk M. Grölla, budzi poważne wątpliwości. Nie tylko druk wygląda dość niestarannie, a czcionka nie przypomina eleganckiej czcionki Grölla, ale wydawca w daleko idący sposób zmienił zapis ortograficzny w stosunku do edycji Gröllowskiej. Znamienne, że druczku tego nie wymienia Z. W ols ki (Spis wydawnictw wyszłych w Dreźnie, Lipsku i Warszawie nakładem lub czcionkami Michała Grela (Groella) drukarza, księgarza i nakładcy polskiego wieku XVIII. Warszawa 1896. Na stronie: http://bc.wbp.lublin.pl/ dlibra/plain-content?id=9660 〈data dostępu: 19 II 2021〉).

Świadczy o tym zamieszczona na końcu oferta książkowa do nabycia u wydawcy w Warszawie i „bey Herrn Hertel zu Leipzig”.

23 Zob. Wahle, op. cit., s. 357, 365.

24 W „Staatsanzeigen” (1791 〈t. 16〉, z. 63, s. 328) w przypisie podano, że tekst został przedrukowany za książką Glavego. Zob. też W a hle, op. cit., s. 365.

25 Zob. „Nouvelles extraordinaires de divers endroits” 1791, nry 49-56.

26 To trochę podważa domniemanie o udziale twórców Ustawy w tym przedsięwzięciu. Co ciekawe, oparte na innej podstawie streszczenia Konstytucji w prasie francuskiej, które ukazywały się w maju, na końcu zawierały notkę: „Après quoi fut déclaration énergique”, i krótką informację o jej treści. 
prawa za tak istotne, że właśnie na nich chciał skupić całą uwagę czytelnika, licząc, być może, iż ma on już jakąś wiedzę na temat okoliczności ustanowienia Konstytucji. Inaczej jest $\mathrm{w}$ pozostałych edycjach. Bukaty także skoncentrował się na treści prawa, jednak potraktował je szerzej. Pierwsze angielskie wydanie Konstytucji (40-stronicowe) zawierało, co prawda, tylko jej tekst (z Deklaracja), ale sygnalizowano w nim, że w przygotowaniu sa przekłady kolejnych ustaw, a konkretnie Prawa o sejmikach ${ }^{27}$. I rzeczywiście, drugie wydanie Konstytucji jest już spora książeczką (liczącą 110 stronic), Ustawie rzadowej towarzyszą zaś przekłady Prawa o sejmikach oraz ustawy Miasta nasze królewskie, czyli Prawa o miastach. Wybór był nieprzypadkowy, obie te ustawy zostały włączone do Konstytucji (art. VI, III) i Bukaty najwyraźniej chciał w pełni pokazać czytelnikom nowy stan prawny. Nie bez znaczenia mogła być także popularność w Anglii reformy miejskiej niemal dorównująca popularności Konstytucji. Wreszcie polski dyplomata wiedział, że wypadki z 3 maja zostały już drobiazgowo zrelacjonowane przez prasę.

Inaczej Glave, który włączył Konstytucje w rozbudowany, oparty na relacji Z „Gazety Narodowej i Obcej” z 7 maja, opis wydarzeń towarzyszących jej ustanowieniu, choć wyraźnie wyróżnił ją graficznie ${ }^{28}$. Konstytucja jest swego rodzaju zwieńczeniem omówionych wcześniej wypadków, lecz nie zamknięciem książki, która zawiera jeszcze krótki opis dalszych wydarzeń (w tym sesji z 5 maja), polemikę $\mathbf{z}$ malkontentami i osobisty, utrzymany we wzniosłym tonie komentarz autora. Czytelnik miał więc nie tylko zapoznać się z nowym prawem, ale też dowiedzieć się o okolicznościach jego powstania, wreszcie wprost wzywano go do poparcia nowej Ustawy. Nie należy zapominać, że tekst Glavego był adresowany tak do cudzoziemców, jak i do niemieckojęzycznych mieszkańców Rzeczypospolitej.

Porównanie tekstów tłumaczeń zacząc wypada od faktu, iż oficjalna nazwa nowego prawa - Ustawa rzadowa - pojawia się na karcie tytułowej jako Forme Constitutionelle tylko w wydaniu francuskim. Niemieckie przedstawiało się jako Geschichte der Polnischen Staatsveränderung, a nazwę Konstytucji przetłumaczoną jako Die Regierungs-Ordnung znajdujemy dopiero na s. 65 nad jej tekstem. W edycji angielskiej nazwa ta nie pojawia się wcale, czytelnik zaś może zapoznać się z New Constitution of the Government of Poland. Co ciekawe, podobna decyzję podją wydawca drugiej edycji niemieckiej, rezygnując $z$ nazwy oficjalnej na rzecz Neue Konstitution von Pohlen. Można odnieść wrażenie, iż obaj posłużyli się tą nazwą - jako bardziej rozpoznawalną - gdyż pod nią właśnie Konstytucja od początku funkcjonowała w Europie. Wszyscy bez wyjątku opatrzyli swoje tytuły datą, z tym że Bukaty pisał o „The Revolution, the Third of May, 1791”, co wiazało się $\mathrm{z}$ angielska narracją o wydarzeniach w Polsce, choć niekoniecznie ucieszyłoby Stanisława Augusta. Stanowisko twórców Ustawy oddaje tytuł francuski, w którym zaznaczono, iż została ona „décrétée par acclamation dans la séance du 3 mai, et sanctionnée à l'unanimité dans la séance suivante du 5 mai 1791". Wpisywało się to w oficjalną akcję propagandową, podkreślającą nie tyle rewolucyjność, ile legalność nowego prawa i sposobu jego ustanowienia.

Zob. The Constitution (wyd. 1), s. 40: „The Law concerning Dietines, or primary Assemblies of Poland, alluded to in the preceding publication, will be published in a few days". 
Jak już powiedziano, było to tłumaczenie właściwie bezbłędne, niemal nieskazitelnie wierne oryginałowi, oddające każdą subtelność tekstu polskiego ${ }^{29}$. Przykładem tego, iż jego autor/autorzy starali się dobierać słowa w sposób staranny i przemyślany, jest tytuł artykułu IV Konstytucji, brzmiący w oryginale Chłopi włościanie. Przysporzył on wiele kłopotów tłumaczom, ostatecznie w wersji niemieckiej pojawił sie jako Adeliche Bauern, a po angielsku dość bezpretensjonalnie jako Peasants and Villagers. Autor przekładu francuskiego zdecydował się na Colons et autres habitants de la campagne. Użył słowa niezbyt popularnego, o czym świadczą wzmianki w prasie francuskiej, w których artykuł ten tytułowano Payssans et vassaux ${ }^{30}$, jednak najlepiej oddającego sytuacje polskich włościan, przynajmniej jeśli wierzyć definicji z Encyclopédie Denisa Diderota ${ }^{31}$. Jeżeli pojawiały się zmiany w stosunku do oryginału, to bardzo drobne, choć nie zawsze bez znaczenia. Niektóre z nich zdają się jakby z lekka wpisywać Konstytucję w dyskurs rewolucyjny częściej pojawiają się słowa „citoyen”32, a także „République”, choć to ostatnie mogło wynikać po prostu z potrzeby doprecyzowania pewnych kwestii, bo słowo to, de facto nie występujące $\mathrm{w}$ oryginale, używane jest też przez autorów pozostałych przekładów. Wzmocnieniu uległo stwierdzenie o swobodach religijnych w artykule II, w wersji francuskiej Konstytucja gwarantowała „une liberté de croyance entière” (s. 5), gdy w polskiej „pokój w wierze i opiekę rządową” (s. 62). Z kolei w artykule IV troskę o włościan dyktować miały „la justice, l'humanité” (s. 10), ale już nie „obowiązki chrześcijańskie", jak w wersji polskiej (s. 65). W artykule VII król nie wypowiada sie już we własnym imieniu, „iż po życiu, jakiego nam dobroć Boska pozwoli [...]" (s. 71), lecz w trzeciej osobie mowa jest o tym, co nastapi po śmierci „du Roi heuresement régnant aujourd'hui [...]" (s. 25). Nawiasem mówiąc, jest to jedyne tłumaczenie, w którym królowi odebrano głos. Są to wszakże korekty bardzo delikatne. Dwukrotnie zdarzyło się autorowi przekładu dodać swój tekst, by wzmocnić przekaz: raz, gdy w artykule VI polskie sformułowanie „wolnemu narodowi polskiemu” (s. 70) uzupełnił „et ne dépendant que d'elle seule [...]' (s. 22), i drugi, kiedy sukcesję uznał „comme le seul moyen d'assurer notre existence politique” (art. VII, s. 25). Były to jednak decyzje rzadkie, nie wpływające w żaden sposób na treść. Czasem zdarzały

29 Poza bardzo drobnymi zmianami wynikłymi $z$ właściwości języka francuskiego, rezygnacją z wtrętów łacińskich (nielicznych) i małymi modyfikacjami w artykule XI.

30 Tak np. w: „Gazette universelle” (1791, nr z 28 V), „Revolutions de France et de Brabante” (1791, nr 79, s. 34), „Gazette nationale ou le Moniteur universelle” (1791, nr z 30 V) i „Le Logographe” (1791, nr z 6 VI; w tekście wydawca używa określenia „le colon”, ale w tytule artykułu się ono nie pojawia).

31 Zob. Colon. Hasło w: Encyclopédie, ou Dictionnaire raisonné des sciences, des arts et des métiers. Mis en ordre et publié par D. Diderot et quant à la partie mathématique, par J. le Rond d'Al e m b e r t. T. 3. Paris 1753, s. 647: „(Jurispr.) du Latin "colonu"s, se dit en quelques provinces pour "fermier d'un bien de campagne". "Colon partiaire", est celui qui au lieu de fermage en argent, rend au propriétaire une certaine partie des fruits en nature. On l'appelle aussi quelquefois "métayer"; mais ce nom ne lui convient que quand la convention est de rendre la moitié des fruits. Quelques-uns ne rendent que le tiers franc, plus ou moins; ce qui dépend de l'usage du lieu \& de la convention". Na stronie: https://fr.wikisource.org/wiki/Page:Diderot_-_Encyclopedie_lere_edition_tome_3.djvu/663 (data dostępu: 15 I 2021).

32 Np. art. VIII (s. 38): „pour [...] toutes les classes de citoyens” („dla wszystkich stanów”, s. 77); podobnie art. II (s. 8): „citoyens” i art. VI (s. 20) „le corps de citoyens” zamiast „naród”. 
się zmiany redakcyjne, powodujące, że tekst stawał się czytelniejszy niż w oryginale (art. VI, s. 17). Zresztą takie zabiegi (udane) można dostrzec we wszystkich tłumaczeniach.

Choć pewna stronniczość frankofona każe mi uznać przekład francuski za najelegantszy językowo, jednak także tłumaczenie niemieckie jest bardzo rzetelne, a jego autor starał się dobrać słowa najlepiej oddające nazwy i określenia polskie. O trudnościach $\mathrm{z}$ tym związanych dwukrotnie wprost poinformował czytelników. Raz przy okazji nazwy „Straży Praw”, następnie - wyjaśniając, dlaczego polskiego „samowładcę” przełożył jako „despotę”, nie używając bliższego słowa „Selbstherrscher", zdaniem tłumacza, za słabo oddającego oryginał ${ }^{33}$. Notabene wydawca drugiej edycji zrezygnował tu $\mathrm{z}$ przypisu, ale za to $\mathrm{w}$ tekście, $\mathrm{w}$ nawiasie podał brzmienie polskie, niemieckie i, co ciekawe, rosyjskie ${ }^{34}$. Bardziej interesujące sa jednak rozważania Glavego na temat możliwości (lub ich braku) wiernego przełożenia nazwy nowego organu wykonawczego. Rzeczywiście, nastręczała ona tłumaczom sporo kłopotu. W wersji francuskiej przetłumaczono ją jako „le Conseil de Surveillance”, po angielsku "the Council of Inspection” 35 , przekład niemiecki wydaje się najbliższy oryginału: „die Wache der Gesetzte” (s. 82). Mimo to tłumacz z niego zrezygnował, wyjaśniając, że Niemcy nie dysponują wystarczająco ładnym odpowiednikiem, który dostatecznie podkreśliłby, iż członkowie tego ciała mają być strażnikami ustaw przyjętych przez przedstawicielstwo narodu ${ }^{36}$. I rzeczywiście, poza nielicznymi wyjątkami tłumacz zachował polskie słowo (w zapisie „Stras”). Co ciekawe, uwagi poniekąd filologiczne stały się dla Glavego punktem wyjścia do refleksji politycznych, które kończył, wyrażając nadzieję, iż także narody składające się na wspólnotę niemiecką z czasem, wzorując się na Polakach, przekształcą ministrów w odwoływalnych strażników państwa (s. 75). Wypada jedynie wspomnieć, że wydawca drugiej edycji nie tylko zrezygnował z tych rozważań, ale dość bezceremonialnie (i niezbyt trafnie) nazwał ów organ „die Staatsrath”, stosując nazwę niewątpliwie bliską czytelnikom niemieckim, lecz dość daleką od postrzegania tej instytucji przez jej twórców. O dobrym orientowaniu się Glavego w niuansach polskiej terminologii politycznej świadczy również określenie sejmu, który po polsku został nazwany „gotowym”. Tak też go przetłumaczył - „der fertige Reichstag”, tymczasem po francusku była to „la diète permanente”, a po angielsku „allways existing" ${ }^{37}$. W zasadzie każda $z$ tych nazw oddawała ideę prawodawstwa zawsze gotowego do działania, ale w kontekście polskich dyskusji: sejm nieustający czy gotowy, należy docenić dokładność tłumacza niemieckiego. Podobnie jak wówczas, kiedy „rokosz” nazwał on „Auffstand des Adels” (s. 102). Tłumacz angielski zaś

Po polsku (art. VII, s. 72) brzmiało to: „Nie samowładcą, ale ojcem [...] narodu [...]”; pozostali tłumacze uznali, że król polski nie jest władcą absolutnym (,monarque absolu”, „absolute monarch”). Zob. Neue Kon

Choć za pierwszym razem pojawiło się też polskie słowo: „Straz, or the Council of Inspection” (s. 20).

On jeden dokładnie przetłumaczył polskie sformułowanie z artykułu VII „Straż praw narodowych” (s. 75), jako „Rath der Wächter der National Gesetze” (s. 91), w wersjach angielskiej i francuskiej była to po prostu „Le Conseil” (s. 33) i „the Council of Inspection” (s. 29).

Choć pojawiło się (za pierwszym razem) określenie „always ready to meet” (s. 17). 
oddał to słowo niezbyt trafnie „insurrection” (s. 41) (18 $^{38} \mathrm{Z}$ kolei przekładając nazwę lokalnych komisji porządkowych Glave wykazał się już nie trafnością językową, lecz znajomością instytucji, użył bowiem określenia „Civil-Kriegs” (s. 92) - istotnie, ich pełna nazwa, która w Konstytucji się nie pojawiła, brzmiała: Komisje Porządkowe Cywilno-Wojskowe. Analogicznie do przekładu francuskiego - tłumacz niemiecki dokonywał czasem zmian stylistycznych, które zresztą poprawiały jasność tekstu ${ }^{39}$, nie było ich jednak wiele, podobnie jak własnych dodatków tłumacza. Najbardziej znaczący znajdował się w artykule IV, gdzie Glave dodał, iż każdy, kto znajdzie się na ziemi polskiej ,freyer Herr und Meister seyn soll" (s. 73), co wzmacniało wymowę tego fragmentu. Jeśli zdarzały się niezręczności lub pomyłki, to nieliczne i bardzo drobne $^{40}$, nie zmieniające treści prawa.

Nie da się tego niestety powiedzieć o przekładzie angielskim. Wydaje się, iż w tym wypadku pośpiech wpłynął niekorzystnie na jakość. W kilku miejscach autor opuścił całe (co prawda, niewielkie) akapity, znikły fragmenty zdań lub pewne sformułowania. Czasem mogła to być decyzja świadoma. Można odnieść wrażenie, że tłumacz w ogóle miał tendencję do upraszczania tekstu, skracania albo pomijania sformułowań będących raczej publicystyką niż tekstem prawa. Tak się stało, gdy skrócił wywód, który przekonywał o konieczności wprowadzenia tronu dziedzicznego w artykule VII, do formuły, iż jest to konieczne "from prudent motives" (s. 21), zapewne uznając, że jest on zbędny dla angielskich odbiorców. Analogicznie w Deklaracji tłumacz opuścił część wyrazów wdzięczności dla Opatrzności za „zdarzoną chwilę pomyślną" (s. 80) oraz związanych z nimi nakazów nabożeństw dziękczynnych. W tym wypadku przypuszczalnie pewne znaczenie miała świadomość, że przekład zaadresowany został do innowierców niechętnych obrzędom katolickim. Podobnie mogło być, gdy informację, iż świętem Konstytucji będzie dzień „świętego Stanisława, biskupa męczennika, patrona Korony Polskiej” (s. 80), a więc 8 maja, tłumacz zastapił enigmatycznym stwierdzeniem, że będzie to „a day, N. N.” (s. 40). Najciekawszy wydaje się skrót dokonany w artykule IV. Otóż rozważania o umowach dziedzica $z$ włościanami $w$ oryginale dość wyraźnie „rozpisano na role”, osobno podane są wynikające $z$ nich powinności pana, osobno chłopów, w tłumaczeniu zostały one połaczone jako "mutual and reciprocal obligation”, obowiąujące obie „contracting parties” (art. IV, s. 10). Ten niewielki zabieg zrównywał w pewnym sensie umawiające się strony i choć nie zmieniał treści prawa, modyfikował, trudno powiedzieć czy celowo, jego wydźwięk. Jednak nie wszystkie zmiany stanowiły mniej czy bardziej świadomą decyzję tłumacza, niektóre są ewidentnie skutkiem pośpiechu. W kilku miejscach wypadły bowiem ustępy będące decyzjami prawa o zniesieniu instrukcji wiążących (art. VI, s. 18), o trybie powoływania ministrów (art. VII, s. 28), czy informacja, że prymas nie podpisuje decyzji Straży (art. VII, s. 25), i fragment o zwoływaniu sejmu w artykule IX o regencji (s. 35). Czasem zdarzają się pomyłki, jak wtedy, gdy zamiast „sejmu teraźniejszego” w preambule pojawiaja się ,future Diets" (s. 5), nie ma ich jednak wiele.

Pod względem językowym tłumaczeniu Bukatego nie da się nic zarzucić, jest 
napisane nie tylko poprawną, lecz ładną i klarowną angielszczyzną, niekiedy klarowniejszą od tekstu oryginału. Tłumacz dokładnie i precyzyjnie oddał $\mathrm{w}$ języku angielskim wszystkie opisy zmian ustrojowych, miejscami może nawet precyzyjniej niż w oryginale (art. V, fragment o sejmie gotowym 〈art. VI $\rangle$ ). Podobnie jak w przekładzie francuskim pewne subtelne zmiany wskazują, że Bukaty starał się nie tylko przetłumaczyć tekst, ale także dostosować go do angielskiego języka politycznego. W preambule pojawiają się prawa naturalne („natural rights”, s. 4), które w polskim oryginale w ogóle nie występują, a dalej - niejako w konsekwencji - podkreślenie, iż ministrowie będą karani za "transgression of positive laws” (art. VII, s. 29), gdy po polsku była mowa po prostu o „przestępstwie prawa” (s. 75). Choć w stosunku do posłów Bukaty używa określenia „nuncios”, jednak przywołując po raz pierwszy izbę poselska, pisze „House of Nuncios, or Deputies” (art. VI, s. 13), co jest wyraźnym nawiązaniem do terminologii angielskiej. Zamiast „ministrów pieczęci” pozostawionych przez innych tłumaczy, pojawiają się „Minister of Justice” i „Minister for the Foreign Affaires” (s. 25) ${ }^{41}$. Czasem doprecyzowuje kwestie, które dla Anglików mogły być niejasne, np. w artykule VI, gdy mowa jest, iż król wyśle propozycje od tronu „województwom, ziemiom i powiatom” (s. 67), tłumacz dodał, że uczyni to „by the circular letters before the Dietines” (s. 14), opisując procedure tradycyjną i oczywistą w Rzeczypospolitej, ale nieznaną Anglikom.

Przekład Bukatego na pewno nie jest tłumaczeniem literalnym, tak jak dwa poprzednie, wydaje się jednak, że mimo to swoją funkcję spełnił dobrze. Wyliczone wcześniej braki mogłyby mieć znaczenie dla odbiorcy polskiego, ale dla czytelników angielskich były to sprawy całkowicie marginalne. Można by nieco przewrotnie powiedzieć, iż tłumaczenie to stanowi wierny przekład Konstytucji, jednak według standardów XVIII-wiecznych, znacznie liberalniejszych niż nam współczesne.

Przedstawione tu omówienie trzech tłumaczeń Konstytucji 3 Maja na pewno nie jest pełne, bo też, jak powiedziano na wstępie, celu tego artykułu nie stanowiła ich szczegółowa analiza filologiczna. Stąd jedynie przykładowo przywoływano tu i starano się porównać decyzje podejmowane przez tłumaczy w odniesieniu do konkretnych sformułowań Ustawy rzadowej, funkcjonujących w niej nazw i pojęć. Już ten krótki i niejako wstępny przegląd pokazuje pewne podobieństwa, a z drugiej strony, także różnice w ustosunkowaniu się do tekstu oryginału. Autorzy omówionych przekładów chcieli jak najczytelniej oddać treść nowego prawa, starali się znaleźć właściwe słowa, by jak najtrafniej przełożyć nazwy instytucji i terminy ustrojowo-prawne. Zarazem także wszyscy próbowali dostosować się do języka politycznego kraju/krajów, w których przekład miał funkcjonować, ale czynili to środkami bardzo subtelnymi, nie zmieniającymi sensu przekładanego tekstu. Jednak strategie translatorskie sa nieco odmienne. Tłumaczenie francuskie miało być, jak się wydaje, w zamierzeniu autora/autorów całkowicie przezroczyste, stanowiło tylko i aż dokument prawa. Przekład niemiecki, choć równie dokładny, był natomiast bardziej osobisty, także $\mathrm{z}$ racji umieszczenia w szerszym kontekście. Jego autor nie ukrywał swoich poglądów, a dwukrotnie odsłonił też kulisy swojej pracy tłumacza. Wreszcie Bukaty przyjął wyraźnie odmienną strategię, traktując

41 W wersjach francuskiej i niemieckiej przetłumaczono literalnie „Ministre de sceaux” (s. 29), „Minister Siegelbewahrer” (s. 88), ale już „Ministre des affaires etrangéres” (s. 30). 
tekst dość ,free a hand", jak mawiają Anglicy, co jest trochę zaskakujące, ponieważ tworzył dokument niemal oficjalny, jeśli się weźmie pod uwagę jego status dyplomatyczny i polecenie króla.

Wydaje się, iż wszystkie trzy przedsięwzięcia okazały się sukcesem zarówno translatorskim jak propagandowym. Ich autorom udało się nie tylko zapoznać z polską Konstytucją różnojęzycznych odbiorców europejskich, ale też oddać jej treść i formę, a zarazem wpisać ją w ówczesny europejski dyskurs polityczny.

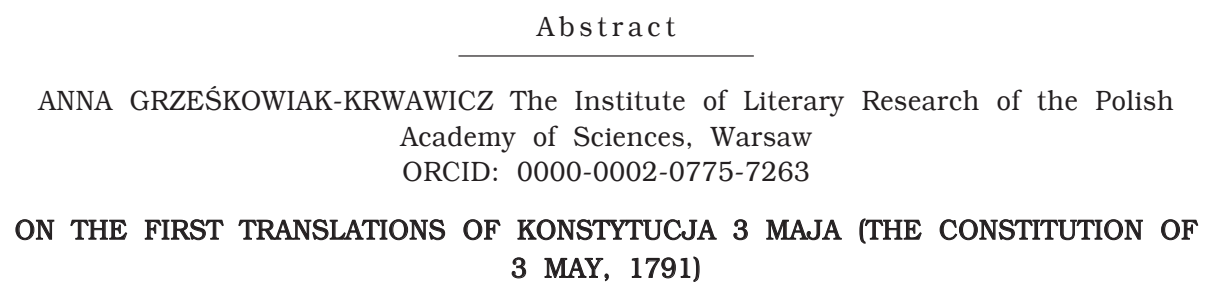

ANNA GRZESKKOWIAK-KRWAWICZ The Institute of Literary Research of the Polish Academy of Sciences, Warsaw ORCID: 0000-0002-0775-7263

\section{ON THE FIRST TRANSLATIONS OF KONSTYTUCJA 3 MAJA (THE CONSTITUTION OF 3 MAY, 1791)}

An analysis of English, French, and German translations of Konstytucja 3 Maja (The Constitution of 3 May, 1791), done in the year 1791, is made subject of the article. The authoress of the study attempts to trace the history of the translations: when they were published, who their authors were, what the circumstances that accompanied their productions were, and how great their extent was. Additionally, she tries to examine the translator's purposes and the ways they strived to accomplish them. This task is linked to an analysis of the translations themselves, their faithfulness to the original, and also with the policy the translators adopted, their attitude to the original, ability to express the Polish content in a foreign language, as well as the with modes of adjusting the discourse to the target receivers' political language. 